\title{
PUBLIC EVENING SCHOOLS OF TRADES
}

\author{
By Charles F. Warner, \\ Principal of the Technical High School, Springfield, Mass.
}

In October, I898, the City of Springfield (Massachusetts) opened the machine shop of its newly established Mechanic Arts High School for evening classes in machine tool work. The city also assumed the responsibility of continuing the plumbing classes of a private trades school which had been carried on for two years without making much progress, and was therefore ready to put its building and such of its equipment as might be used at the disposal of the public school authorities. These classes in machine tool work and plumbing formed the beginnings of the Springfield Evening School of Trades-the first trades school in the United States to be supported at public expense.

The first classes organized under this new departure were necessarily conducted on a somewhat experimental plan, but they immediately became popular with the local mechanics, and the first season proved to be very successful. Not only was the instruction promptly acknowledged to be of great value to the men who received it, but it was no less promptly seen to be of general profit to the trades represented. Before the close of the first year the Master Plumbers' Association voluntarily agreed, in employing help, to give the preference to members of the evening classes in plumbing. Leading representatives of the iron-working tracles expressed approval, and advised their employees to join the machine shop classes. This early success encouraged the authorities to expand the work of the school. Classes in patternmaking and other kinds of woodwork were added at the beginning of the second session, and the enrolment in these classes, though less than that in the machine-shop work, has steadily increased. A class in mathematics for mechanics was organized at the opening of school in October, I90I, and it proved to be a valuable addition. The enrolment in this work during the years following is evidence of the growing appreciation of the value of such instruction. There are now two classes-an elementary and 
an advanced class, which together cover a wide range of mathematical subjects. A lecture course in electricity and magnetism was also started in I901, and the following year this work was extended by the addition of two laboratory classes in applied electricity, each meeting twice a week. These classes have met the popular interest in electrical subjects, and the work already accomplished justifies their continuance. In this same year (IgOI) the evening mechanical drawing classes, which under the Massachusetts statute of 1870 had already been in operation thirty years, were transferred to the Evening School of Trades. It will be seen that the work of this school now included thorough instruction in mechanical drawing, machine-shop practice and toolmaking, plumbing, joinery, cabinetmaking, wood turning and patternmaking, shop mathematics and electricity. The enrolment for the season of $1907-8$ amounted to 396 , and the attendance has always been remarkably constant, showing a much higher percentage than is common in evening schools. It was evident from the first that the expense of maintaining this important addition to the public school system of Springfield would not be a serious matter, and the successive city governments, almost invariably, have promptly voted the moderate sum required.

As a pioneer in this most practical phase of American public school work and also because of its prompt success, the Springfield Evening Trades School attracted very wide attention, not only in this country, but also abroad. Following the example of Springfield, other American cities-notably Cambridge, Hartford, and Cleveland-have opened up the shops of their manual training schools for the instruction of mechanics in evening classes. In every case the results have amply justified the plan of utilizing the equipment and teachers of manual arts schools already established for the instruction of mechanics, apprentices, or others closely associated with work in the manual arts, in such processes of the fundamental trades as could be well taught in this way.

The general aim of the evening trades schools is to give men already employed in the trades a chance to broaden their technical training and thus make themselves more efficient workmen. They have been sometimes classified as continuation schools, borrowing a term that is much used in designating evening schools for workmen in foreign countries. But they differ from foreign continuation 
schools in one important respect, viz., in placing the major emphasis upon training in the school shops. Generally speaking, the object of the continuation schools of Germany and England is to extend the training of the elementary schools in language, mathematics, drawing, and science, with special reference to applications of these subjects in the leading industries of the community where the school is located. Direct training in the use of tools and machines is left to the shops and factories where the members of the school are employed during the day either on part time or on full time. In so far as evening trades schools of the American type give instruction in mathematics, mechanical clrawing, and science, they resemble foreign schools of the kind referred to; but their main object at the present stage of their development is to supplement the imperfect and highly specialized training of modern shops by giving machine hands, helpers, and apprentices, so far as there are any apprentices, an opportunity to gain practice in a greater variety of actual shop work than is ever likely to be open to any one man under the modern system of machine production. The mechanic's chief aim in entering these schools is to acquire a wider range of practical knowledge and to improve the quality of his work in order to reach in his trade a higher classification, with increased wages. Some recent statistics of the Springfield Evening Trades School show plainly the general character of the clientele of such schools and the main purpose of those who attend. These facts appear in the following tabular statement, in which the figures given include the entire enrolment in the various classes:

Experience in trade taught:

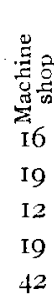

Some experience in other employment . . 77 Aim in taking course:

To improve knowledge of trade ... 83

${ }^{1}$ To learn a trade .............. I6

To gain general information ....... Ir

\begin{tabular}{|c|c|c|}
\hline 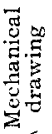 & 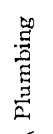 & $\frac{D}{8}$ \\
\hline 96 & 16 & 9 \\
\hline$\ldots$ & 6 & 2 \\
\hline 2 & I3 & 5 \\
\hline$\cdots$ & 8 & 4 \\
\hline 2 & 4 & . \\
\hline 96 & $2 \mathrm{I}$ & 9 \\
\hline 4 & 28 & 8 \\
\hline 8 & $I_{4}$ & 8 \\
\hline 88 & 4 & 4 \\
\hline
\end{tabular}

${ }^{1}$ Apprentices in plumbing; merely beginners in other trades. 
A comparative study of the statistics given in this table reveals several interesting facts. About one-third of the men were enrolled for instruction in the mechanical drawing classes. Only four per cent of these, however, had actually been employed in that line of work, and of the remaining ninety-six per cent eight per cent only wished to become draftsmen, while eighty-eight per cent were engaged permanently in some other work in which a knowledge of drafting would be of service. These figures sustain in a marked degree the statement often expressed with reference to the effect of the Massachusetts law of 1870 , which requires all towns in the commonwealth of ten thousand inhabitants or more to maintain an evening drafting school. Contrary to the expectation of some of the framers of the law, these classes do not turn out draftsmen in large numbers, but they afford an opportunity for acquiring a knowledge of the meaning of working drawings and how they are made-information of great value in many occupations.

Turning to the table again, we find that more than two-thirds of the enrolment is for instruction in the strictly mechanical trades. This indicates a greater demand for the direct shop training peculiar to American trade schools than for the broader and more general, though no less practical instruction given in the continuation schools of foreign countries. It should be mentioned, too, that in the Springfield school, although tuition is free to all residents of the city, an incidental fee varying from $\$ 4.00$ to $\$ 8.00$ is charged in the machine shop, plumbing, woodworking, and electrical classes, while no fee at all is charged for mechanical drawing. This fact makes the larger total enrolment in the shop classes even more significant.

It will be noted also that a considerable number of those enrolled in the shop classes, particularly in the machine shop, had already had several years' experience in the trades they were following, and yet they felt the need of trades teaching. There were comparatively few beginners or apprentices. A considerable percentage of beginners, however, was found in the plumbing, woodworking, and electrical classes; and in plumbing these beginners were apprentices from the local shops. But in the machine shop we find that nearly half the men had had over three years' experience, while less than one-sixth of the enrolment was made up of beginners. Most of these men knew something about machine tool work. Their experience, however, had been limited to one machine or at most to 
two or three. The school afforded them an opportunity to become familiar with a large number of the fundamental machine tools of the modern shop, an opportunity which the modern shop itself does not afford.

But perhaps the most significant fact of all revealed by the table is found in the large numbers who had had more or less experience in employments different from those which they were following or for which they wished to receive preparation in the trades school. About three-fourths of those enrolled in the machine shop had drifted into this work from other trades or occupations. Nearly half of those in the plumbing classes and in the woodworking classes had done the same thing. This is merely another demonstration of the well-known fact that large numbers of our young mechanics drift about from one employment to another, more or less unskilled, before they find themselves well enough grounded in any trade to be able to claim honestly a fair knowledge of it. In fact, the welltrained, skilful mechanic in any trade is rarely to be found.

Objection will be made that evening trades schools, though they may be able to do some good in the industrial world, must always fall far short of fully satisfying the demand for training in the trades. It is true that an ideal scheme of industrial education, which has for its object the upbuilding of all lines of industry, as the result of the training of the workers in skill and efficiency without neglecting their physical, intellectual, and moral well being, must assume the possibility of a more thorough and far more comprehensive plan of operation than can be carried out in any system of evening schools. But these schools do not claim to offer a complete and perfect solution of the problem of industrial education. They do offer, however, a partial solution of great value which may open the way to a very wide extension of public school work to meet the new demands of a machine-working age. So long as evening trades schools depend for their existence and for the scope of their work upon the shops and equipments of manual training schools, which are comparatively few in number and rarely extensive, their usefulness must be confined within comparatively narrow bounds. But why need they be thus confined? While the need for industrial education is one of the great public questions of the day, demanding the attention of educators, legislators and all associations of men 
interested in social progress, it is also a question that appeals to the private interests of the manufacturer and the wage earner. It, therefore, calls for co-operation between the schools on the one hand, as representing public interests, and manufacturers' associations and labor organizations on the other, as representing private interests. Here is a wide field for co-operation in which the manual training schools, as now equipped and carried on, may be of service. What they need and what they should have, in order to make them more effective, is encouragement and enlargement through the cooperation of the other interests concerned. It would be an easy matter to enlarge the evening trades schools and extend their usefulness under public management if all the interests concerned would take hold of the matter earnestly and contribute their just share in expense and effort. This is already being done in some sections, and all friends of industrial education will find encouragement in the growth of the co-operative spirit.

It is admitted that evening trades schools at their best cannot fully meet industrial needs. They have their natural limitations. The courses which they offer must be brief and intensely practical. Evening work in itself, however keen the interest, lacks the freshness and vitality of similar educational work done in the daytime. The clientele of the evening schools is naturally made up of those beyond the ordinary school age or of adults, because the need for this training has been impressed upon them by their first contact with industrial life. Not all the workers, however, have come through the years of transition between the period of elementary education, if they had any, and the age when their productive work should begin, with a desire for training and an appreciation of its value. The greatest industrial need is an effective plan for taking advantage of our industrial resources. This problem will find its best solution without doubt in day trades schools. Meantime, and perhaps for many years, evening trades schools have their mission. They will attract large numbers and a great variety of workmen. Those who attend them will always have a definite and sincere purpose, and they will secure promptly the training and information which they need. The laborer, the employer, and the taxpayer will appreciate the value of such instruction. Such schools cannot fail to give a direct, practical solution to much of our present industrial need. This alone would be enough to justify every effort that may be 
made for their further development. But these schools should interest the friends of industrial education for another reason. They will teach by example the possibility of trade training under public auspices and show the value of it to the manufacturer, to the wage-earner, and to the communities which both serve. This will be of great assistance in the solution of the problem of creating a complete and comprehensive system of industrial education in connection with our public schools.

Course of Instruction in the Springfield Evening School of Trades

Mechanical Drawing.

Machine Drawing Course.

First Year.-(I) Working drawings from models and sketches. (2) Principles of projection. (3) Intersections of solids and development of surfaces.

Second Year.-(1) Screw threads. (2) Working drawings from sketches and models of machine parts. (3) Isometric drawing.

Third Year.-Mechanical Motions: (I) Cams. (2) Levers. (3) Gears.

An advanced course in Machine Design is open to those who have completed the course in Machine Drawing and who have the requisite knowledge in mathematics.

\section{Architectural Drazing Coursc.}

First Year.-Same as Machine Drawing Course.

Second Year.-(I) Details showing architectural construction. (2) The orders of architecture.

Third Ycar--(I) Details of construction. (2) Architectural perspective.

An advanced course in Architectural Design is open to those who have completed the Architectural Drawing Course and are otherwise fitted for this work.

\section{Machine Shop Practice.}

Two Evenings Each Week for 24 Weeks.

First Year.-(I) Working in sheet metal-straight and curved formsbench work. (2) Working in cast and wrought iron-chipping and filingbench work. (3-4) Hand turning on speed lathe-(a) working to drawings, with practice in use of taps and dies-(b) working to template. (5) Straight and taper turning on speed lathe, with practice in use of slide rest. (6) Straight and taper boring on speed lathe, with use of slide rest. (7) Work on face plate-practice with center indicator. (8) Elementary work on engine lathe, shaper, and milling machine.

Second Year-(1) Practice in straight and taper turning. (2) Practice in screw thread cutting. (3) Practice on milling machine, with use of index centers. (4) Practice in use of nut mandrels. (5) Chucking in lathe with 
inside thread cutting. (6) Center rest problems on engine lathe. (7) Face plate work in connection with the laying-out plate. (8) Template work, with practice in irregular shapes.

Third Year-(I) Vise work on planer or shaper. (2) Work on platen and strip of planer. (3) Work with tse of V blocks on planer. (4) Work in connection with laying-ont plate on planer. (5) Making and use of eccentric mandrel on lathe. (6) Making and assembling simple machines or fixtures, such as bench drills, bench centers, bench shears, milling cutters, grinders, drill jigs, milling fixtures, or punches and dies.

ToOL-MaKing.

Two Evenings Each Week for 24 Weeks.

First Year.-(I) Sheet steel gauges and templates-straight, angular, and curved forms-bench work. (2) Practice in turning to drawings-simple forms. (3) Shaping cutter blanks-straight and taper turning-use of slide rest. (4) Mill and model blanks-irregular shapes-turning to template. (5) Fly cutters and formers-bench work. (6) Shank mills and cutters-lathe and milling machine, with index centers. (7) Counterbores, with practice in hardening, tempering and grinding. (8) Practice in hand grinding and sharpening tools.

Second Year.-(I) Nut mandrel. (2)Thread arbor and mill. (3) Milling cutters-straight face and side cut. (4) Beveled and backed off milling cutters. (5) Special and irregular forms of milling cutters. (6) Spiral milling cutters, reamers, and twist drills. (7) Special practice in universal cutter grinding.

Third Ycar.-(1) Internal cylindrical gauges. (2) External cylindrical gauges. (3) Taps and dies. (4) Punches and dies. (5) Drill jigs. (6) Special work on universal milling machine and special features of tool work.

\section{WoOd-'TuRning.}

(I) Explanation of the speed lathe and instruction in the use and care of tools. (2) Mounting work for turning between centers. (3) Exercises in turning between centers, such as plain cylinders, square shoulders, beads, grooves, tool handles, balusters. (4) Exercises in face-plate turning, and polishing work in lathes, such as rosettes, corner blocks, rings, boxes.

\section{Pattern-Making.}

(I) Explanation of rules for allowances for shrinkage, for draft and for finish, both for iron and brass castings; and of the methods employed in varnishing and finishing patterns. (2) Making and finishing plain patterns, such as those for washers, lathe handles, face-plates, journal boxes, stuffing boxes and glands, bevel gear blanks, brackets, plain pulleys, cone pulleys, pillow blocks. (3) Making and finishing patterns which require core boxes, such as pipe elbows, tees, and valves. (4) Making and finishing patterns which require intricate coring, or other accurate work, such as patterns for 
milling machine parts, for lathes, for complete pieces of school apparatus, for spur and bevel gears, for steam and gasoline engine parts.

\section{Cabinet Making and Furniture Making.}

The work in this course is limited to articles for home use, made according to special designs and drawings.

\section{Plumbing.}

WATER SUPPLY.

\section{Lectures-First Year Class:}

I. Country Water Supply.-( I) Wells; (2) Pumps; (3) Tube Wells; (4) Hydraulic Ram.

2. City Water Supply.-(I) Water Mains; (2) Service Pipes.

3. Street and Tank Systems.-Street Main Connections.

4. Friction.-Water Hammer.-(I) Water Pressure Regulators; (2) Air Locks.

5. Meters.-Filters.-Tanks._(I) Tank Valves; (2) Faucets; (3) Ball Cocks.

6. Boilers, Single and Double.-(I) Vertical and Horizontal Boilers, (2) Instantaneous Heaters; (3) Circulation; (4) Expansion.

7. Metals and Alloys.-Joint Making.

\section{Practice Work-First Year Class.}

The object of the practice work of the first year is to teach how joints on supply pipe work are made and to give practice in installing supply pipes and fixtures. It includes the following main topics:

Methods of joining metals. Tools. Names and use. Preparing pipe ends. Straightening pipe. Tacks-making and putting on. Cleaning and testing solder. Cup joints. Overcast joints. Wiped joints: Round, upright, and underhand; Branch, underhand, upright, side; Branch, 3-way, 4-way; Faucets and stop cocks. Packing bibbs and ball cocks. Setting up and connecting boiler with range and tank. Tank lining and general water supply.

\section{SANITARY DRAINAGE.}

Lectures-Second Year or Advanced Class.

I. Principles of Hygiene.

2. Sanitary Drainage.-( I) Subsoil Drainage; (2) Cesspools; (3) Cellar Drainage; (4) House Drainage; (5) Land Irrigation Disposal.

3. House Ventilation.-(I) Fresh Air Inlets; (2) Frozen Vent Pipes; (3) Drainage Ventilation.

4. Drainage Systems.-(I) Standard; (2) Durham; (3) Pike; (4) 2oth Century.

5. The Siphon and its Action in House Plumbing.

6. Traps.-(I) Special Makes; (2) Grease Traps; (3) Proper Venting.

7. Fixtures-Arrangement and Care of Same. 


\section{Practice Work-Second Year Class.}

Making joints on waste and drainage work; on $\mathrm{I} / 4$-inch $\mathrm{T}$ branch, $\mathrm{Y}$ branch; on 2 -inch ferrule, 4-inch ferrule; on flanges, side and upright; on electric conduit. Making bends, offsets, sand and spring; soil pipe joints, upright and underhand. Setting up soil pipe for various systems of venting. Setting up plumbing fixtures.

The supplementary course in lead burning includes instruction in but seam, flat and vertical lapped joints, vertical and tee pipe joints, and tank lining.

\section{Shop Mathematics.}

The aim of the courses in shop mathematics is twofold-first, to teach the methods of computation necessary for the solution of the common problems arising in shop practice; second, to present in condensed form the essentials of algebra, geometry, and trigonometry for the benefit of those who have not had a high school training, and to show the applications of these subjects to the more advanced types of shop problems. This twofold aim leads to a natural division of the work into two courses:

\section{Course I, Elementary-Shop Arithmetic.}

This course comprises work with common and decimal fractions, measurements, percentages, ratio and proportion, square and cube root; applying these principles to such shop problems as gearing, simple and compound, how to select gears to cut screws and spirals, computations on the lever, including the lathe indicator, lever safety valve, the Prony brake; pulleys and hoists, simple, compound, and differential indexing with the milling machine; problems connected with the speed lathe and engine lathe, computing the horse power of steam engines, electric dynamos and motors.

Course II, Advanced-Algebra, Geometry, and Trigonometry, with applications to shop work.

This course is open to those who have completed Course I or who have had a preparation equivalent to a good grammar school education. It treats of the most important principles of algebra, especially of the equation as a means of solving problems, and of the derivation and use of formulas. The practical side of geometry is next taken, emphasizing the methods of finding areas and volumes, weights of bars of various shapes and materials, heating surface of boilers, etc. The last half of this course is spent on trigonometry including the use of logarithms and logarithmic tables and emphasizing the applications of trigonometry to the more advanced types of shop problems.

\section{ELECTRICITY.}

LECTURES.

One lecture per week on the principles of electricity is given in both courses. The subjects are as follows:

(1) Magnetism. (2) Static electricity. (3) Voltaic cells. (4) Storage 
cells. (5) Electrolysis. Plating. (6) Electro-magnetism. (7) Applications of electro-magnets. (8) Heating effects of the current. (9-II) Measurement of current and resistance. (12) Ohm's law, electro-motive force. (13) Divided circuits. (14) Electric lighting. (15) Electro-magnetic induction. (16) Principles of dynamos and motors. (17) Armature windings. (18) Constructive details of dynamos and motors. (I9) Management of machines. (20) Power stations. Railways. (2I) Alternating currents. (22) Telephony. (23) High potential phenomena. (24) Wireless telegraphy.

\section{LABORATORY InSTRUCTION.}

\section{Elementary Course.}

The practical work for beginners aims to show by exercises in actual construction, the proper methods of installing varions electric circuits, fittings and apparatus, simulating as closely as possible the conditions met with in outside work.

In addition to the practice in construction a few exercises in electrical measurements and tests are given.

The list of elementary exercises is as follows:

(1) Magnetic fields. (2) Study of simple voltaic cell and battery elements. (3) Study of two-fluid cell. (4) Setting up and connecting battery cells. (5) Helix, relation of popularity to direction of current. (6) Wire cutting, joining, soldering, taping. ( $7-\mathrm{II})$ Bell circuits. (12-14) Electric gas lighting circuits. (15-20) Two-wire incandescent lighting circuits. (2I) Electro-plating. (22) Three-wire lighting circuits. (23-24) Three-wire circuits. (25) Measurement of resistance by substitution method. (26-27) Measurement of resistance by drop method. (28) Testing for grounds with magneto. (29) Insulation resistance by voltmeter. (30) Test of circuit breaker. (31-32) Connecting up and operating motor and dynamo. (33) Installation of intercommunicating telephone system. (34) Installation of intercommunicating telephone system. (35-37) Wiring switchboard for parallel operation of dynamos. (38) Operation of dynamos in parallel. (39) Operation of isolated lighting and power plant. (40) Calibration of ammeter by direct comparison. (4I) Load curve reading and plotting from school plant. (42) Taping and winding small solenoid. (43-44) Cure and operation of "diseased" motor. (45) Measurement of watts taken by 16 c. p. lamp at aifferent voltages. (46) Effect on resistance of temperature of filament of lamp. (47) Charge and discharge of small storage cell. (48) Winding of small motor parts for successful operation under current. (49) Candle power of incandescent lamps, photometer work.

\section{Advanced Course.}

In advanced work the wiring exercises are omitted and the following list of measurements and tests substituted:

(I-2) Calibration of tangent galvanometer by copper voltameter. (3) Measurement of resistance by Wheatstone bridge. (4) Effect of temperature on resistance. Specific resistance. (5) Measurement of the internal resis- 
tance of cells. (6) Operation of motor. (7-8) Shunt characteristic of a dynamo. (9) Effect of field strength on voltage. Effect of speed on voltage. (Io-II) Cure and operation of dynamo that fails to build up. (I2-I3) Operation of small motor and test of its brake horse power. (14) Effects of ampere turns on field. Compounding a shunt dynamo. (15) Practice in armature winding. (16) Practice in field winding. 